\title{
ANALYSIS OF THE MARKOWITZ METHOD AND THE SINGLE INDEX METHOD IN DETERMINING THE OPTIMAL PORTFOLIO
}

\author{
Dhea Eka Fitriyani \\ Universitas Langlangbuana, Indonesia \\ dheaekaftryn@gmail.com
}

\begin{abstract}
Investors generally make investments to get the maximum return with minimal risk. The optimal portfolio is a method that can be used to determine the stock portfolio that produces the maximum return with the least risk. The purpose of this study is to determine the accuracy of the Markowitz method and the single index method in determining the optimal portfolio and to determine whether or not there are differences in the results of optimal portfolio calculations using the Markowitz Method and the Single Index Method. The study population includes LQ-45 companies listed on the Indonesia Stock Exchange for the period 2014-2018. The sampling method used in this study was purposive sampling, based on predetermined criteria obtained from 18 sample companies. The method used is the One-Sample t-Test and the Independent Sample tTest. The results of this study indicate that there is no difference between the Markowitz Method and the Single Index Method in determining the Optimal Portfolio.
\end{abstract}

Keywords: Optimal Portfolio; Markowitz Method; Single Index Method

\section{INTRODUCTION}

Investment is a form of investment, either directly or indirectly, with the hope that later it will get added value benefits or other forms of benefits from the investment. For investors (investors), the capital market is a means of investing in financial instruments such as stocks, bonds, mutual funds, etc. following the characteristics of the advantages and risks of each instrument. A capital market company is a place to get funds from the community for business development, expansion, additional working capital, and so on. Investments are made to bring returns, but calculating returns alone is not enough, the risk of investing also needs to be taken into account. Investors in investing always try to minimize the various risks that arise, both short and long-term.

Stock risk is generally divided into two, namely systematic risk and unsystematic risk (Zubir, 2011: 19). Systematic risk is a market risk that cannot be avoided by investors, while the unsystematic risk is a company risk that can be avoided or minimized through diversification. With diversification, the portfolio will be safer because the risk is spread across various investment instruments, by raising investor funds, investment companies allow investors to hold a small portion of many different securities (Bodie, 2014). According to Hartono (2013), only portfolios that provide the smallest risk with the same expected returns are efficient. A portfolio is a set of investment instruments designed to meet general investment objectives. A portfolio can also be interpreted as a combination of various assets/ securities/ shares/ investment opportunities (Rodoni \& Ali, 2014).

In Indonesia, there is a stock exchange, namely the Indonesia Stock Exchange, which is located in Jakarta. The Exchange has created an index containing shares of companies that have high liquidity, are objective, have large market capitalization, good corporate financial conditions, and good fundamental conditions, namely the Liquid 45 index or better known as the LQ 45 Index group.

To analyze a portfolio, several calculation procedures are needed through several data as input on the structure of the portfolio. Portfolio analysis models that can be used by investors include the Markowitz Model, the Single Index Model, the Capital Asset Pricing Model (CAPM), and the Arbitrage Pricing Theory (APT). 
This study using a portfolio analysis of the Markowitz Model and the Single Index Model. The reason for using the Markowitz Method is because the investor's preference is only based on the expected return and risk of the portfolio, while the reason for using the Single Index Method is because this method can simplify the calculation of the Markowitz Method and provide input parameters for Markowitz calculations.

Although LQ-45 contains stocks of companies that have high liquidity, are objective, and have large market capitalization, there is still uncertainty about the returns received by investors. As based on Table 1 below, it can be concluded that the LQ-45 return fluctuates and has experienced a decline, this indicates that there is an element of risk in the investment.

Table 1. LQ-45 Return Data for 2014-2018

\begin{tabular}{crr}
\hline Year & Return LQ 45 & Return LQ 45 (in\%) \\
\hline 2014 & 0.0295 & $2.95 \%$ \\
2015 & -0.0129 & $-1.29 \%$ \\
2016 & 0.0189 & $1.89 \%$ \\
2017 & 0.0039 & $0.39 \%$ \\
2018 & -0.0053 & $-0.53 \%$ \\
\hline rce: Data from yahoo finance processed by the author (2019)
\end{tabular}

Rahmadin's research (2014) states that investors should choose stocks that are members of the LQ 45 Index in the 2011-2013 period which can form an optimal portfolio stock with each proportion consisting of Unilever Indonesia Tbk. (UNVR) with a proportion of $25.96 \%$, Telekomunikasi Indonesia (Persero) Tbk. (TLKM) with a proportion of $25.98 \%$, Kalbe Farma Tbk. (KLBF) with a proportion of $37.17 \%$, Jasa Marga (Persero) Tbk. (JSMR) with a proportion of $9.75 \%$, Astra International Tbk. (ASII) with a proportion of $0.66 \%$, Charoen Pokphand Indonesia Tbk. (CPIN) with a proportion of $0.48 \%$. There is a background problem that has been described, the authors are interested in conducting this research to know the accuracy of the Markowitz method and the single index method in determining the optimal portfolio, and to find out whether there is a difference between the Markowitz method and the single index method in determining the optimal portfolio.

\section{METHODS}

The type of research used in this research is comparative with quantitative descriptive methods. This research was conducted by collecting data from the Indonesia Stock Exchange (BEI) through the website www.idx.co.id and finance.yahoo.com. The data source used in this research is secondary data. And the research data used is historical data from the closing price of LQ-45 shares during the 2014-2018 period.

This study uses non-participant observation data collection. Data collection in this study was carried out with a series of activities to obtain secondary data, activities carried out were: (1) Library Research, (2) Data collection through several internet sites. Retrieval of share price data on the IDX website and yahoo finance. The population of this study is companies listed on the LQ-45 Index listed on the Indonesia Stock Exchange.

This study uses the purposive sampling technique, where the sampling technique used by the researcher has certain considerations in sampling. The sample criteria are as follows: (1) Companies that are sampled are companies whose shares are listed on the LQ-45 Index for the 2014-2018 period, (2) The companies sampled are companies that are consistently included as members of the LQ-45 Index for the 2014-2018 period, (3) Companies sampled are non-financial companies. Financial firms (banking) are not included in the sample. 
Based on the above criteria, 18 companies meet the criteria as a sample. The sample companies are as follows:

Table 2. Research sample

\begin{tabular}{ccc}
\hline & Ticker & Nama Emiten \\
\hline 1 & ADHI & Adhi Karya (Persero) Tbk \\
2 & ADRO & Adaro Energy Tbk \\
3 & AKRA & AKR Corporindo Tbk \\
4 & ASII & Astra International Tbk \\
5 & BSDE & PT Bumi Serpong Damai Tbk \\
6 & GGRM & Gudang Garam Tbk \\
7 & INDF & Indofood Sukses Makmur Tbk \\
8 & JSMR & Jasa Marga Tbk \\
9 & KLBF & Kalbe Farma Tbk \\
10 & LPKR & Lippo Karawaci Tbk \\
11 & PGAS & PT Perusahaan Gas Negara \\
& & Tbk \\
12 & PTBA & Tambang Batubara Bukit \\
& \multicolumn{2}{c}{ Asam Tbk } \\
13 & SMGR & Semen Indonesia (Persero) \\
& & Tbk \\
14 & TLKM & PT Telekomunikasi Indonesia \\
& & (Persero) Tbk \\
15 & UNTR & United Tractors Tbk \\
16 & UNVR & Unilever Indonesia Tbk \\
17 & WIKA & Wijaya Karta Tbk \\
18 & WSKT & PT Waskita Karya (Persero) \\
& & Tbk \\
\hline
\end{tabular}

Source: Data from sahamok processed by the author (2019)

In this study, the analysis was carried out using two methods, namely the Markowitz method and the single index method to determine the optimal portfolio. Statistical data analysis in this study used the Shapiro Wilk normality test and hypothesis testing. The normality test is a test carried out to assess the distribution of data for a group of data or variables. Is the data distribution normal or not. The criteria used in the Shapiro Wilk normality test are as follows: (1) If the significance value is $>0.05$, then the research data is normally distributed, (2) If the significance value is $<0.05$, then the research data is not normally distributed. Meanwhile, to test the hypothesis, this study uses the t-test, namely one-sample t-test, and independent-sample t-test.

\section{Descriptive Analysis}

\section{RESULTS AND DISCUSSION}

This study aims to determine the optimal portfolio by using two methods, namely the Markowitz method and the single index method in the LQ-45 Index stock group on the Indonesia Stock Exchange in the 2014-2018 period. The results of the descriptive analysis that have been managed are: 


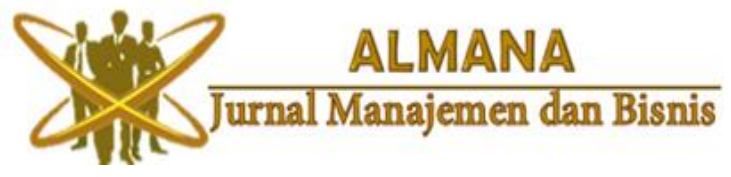

Table 3. Descriptive Statistics of the Markowitz Method

Descriptive Statistics

\begin{tabular}{lcccccc}
\hline & N & Minimum & Maximum & \multicolumn{2}{c}{ Mean } & Std. Deviation \\
& Statistic & Statistic & Statistic & Statistic & Std. Error & Statistic \\
\hline Markowitz & 18 & -.01655 & .03089 & .0068000 & .00233975 & .00992672 \\
Valid N (listwise) & 18 & & & & & \\
\hline
\end{tabular}

Source: SPSS 24 output results (2019)

From the results of the descriptive analysis that has been carried out in Table 3 that $\mathrm{N}$ on the Markowitz Method variable or the number of samples of 18 company stocks. The data used is proven valid with $\mathrm{N}$ of 18 company stock samples. The Markowitz method variable in the results of the descriptive analysis has a mean or average value of 0.0068 and a standard error value of 0.00234 and has a standard deviation value or a large risk value of 0.00993 . With the minimum value or the lowest value of -0.01655 and the maximum or highest value of 0.03089 .

Table 4. Descriptive Statistics of Single Index Method

\section{Descriptive Statistics}

\begin{tabular}{lrccccc}
\hline & $\mathrm{N}$ & Minimum & Maximum & \multicolumn{2}{c}{ Mean } & Std. Deviation \\
& Statistic & Statistic & Statistic & Statistic & Std. Error & Statistic \\
\hline Singlelndex & 18 & -.02085 & .01448 & .0013139 & .00188085 & .00797978 \\
Valid N (listwise) & 18 & & & & & \\
\hline
\end{tabular}

Source: SPSS 24 output results (2019)

From the results of the descriptive analysis that has been carried out, it can be seen in Table 4 that $\mathrm{N}$ for the single index method variable or the number of samples of 18 company stocks. And used proven valid with $\mathrm{N}$ several 18 company stock samples. The single index method variable in the results of the descriptive analysis has a mean or average value of 0.00131 and a standard error value of 0.00188 and has a standard deviation value or a large risk of 0.00798 . The minimum value or the lowest value is 0.02085 and the maximum value or the highest value is 0.01448 .

Optimal portfolio analysis using the Markowitz method has criteria for stocks that are included as optimal portfolio candidates, namely the value of the expected return $(E$ $\left.\left(R_{i}\right)\right)$ is greater than the value of the market return $\left(R_{m}\right)$.

\section{Verificative Analysis} follows:

In this analysis there is a Shapiro Wilk normality test and hypothesis testing as 


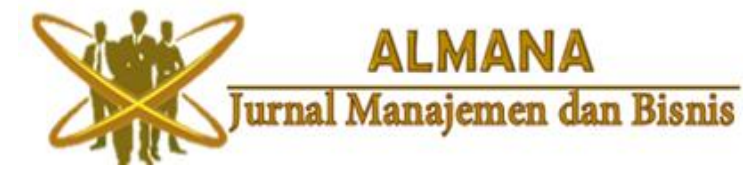

Table 5. Normality Test Results using the Shapiro Wilk Test with the Markowitz Method and the Single Index Method

Tests of Normality

\begin{tabular}{lcccccc}
\hline & \multicolumn{3}{c}{ Kolmogorov-Smirnov } & \multicolumn{3}{c}{ Shapiro-Wilk } \\
& Statistic & $\mathrm{df}$ & Sig. & Statistic & df & Sig. \\
\hline Markowitz & .170 & 18 & .180 & .942 & 18 & .312 \\
Singlelndex & .139 & 18 & $.200^{*}$ & .924 & 18 & .152 \\
*. This is a lower bound of the true significance. \\
a. Lilliefors Significance Correction \\
\hline
\end{tabular}

Source: SPSS 24 output results (2019)

In Table 5, it can be seen that the significance value of the Shapiro Wilk test is 0.312 for the Markowitz Method and 0.152 for the Single Index Method. This means that the two data are normally distributed because they have a significant value of 0.312 and $0.152>0.05$. This shows that the data in this study are normally distributed. So the next step is to test the significance of differences, using the one-sample t-test and the independent sample t-test.

The hypothesis test used in this test is the one-sample t-test. One sample t-test is an analytical technique to compare one independent variable. This technique is used to test whether or not certain values differ significantly from the average of a sample.

Hypothesis testing of the Markowitz method, namely:

Ho: The Markowitz method is not accurate in determining the Optimal Portfolio on LQ45 group stocks on the IDX.

Ha: The Markowitz method is accurate in determining the Optimal Portfolio on LQ-45 group stocks on the IDX.

Table 6. One-Sample T-Test with the Markowitz Method

One-Sample Test

\begin{tabular}{|c|c|c|c|c|c|c|}
\hline & \multicolumn{6}{|c|}{ Test Value $=0$} \\
\hline & \multirow[b]{2}{*}{$t$} & \multirow[b]{2}{*}{ df } & \multirow[b]{2}{*}{ Sig. (2-tailed) } & \multirow{2}{*}{$\begin{array}{c}\text { Mean } \\
\text { Difference }\end{array}$} & \multicolumn{2}{|c|}{$\begin{array}{l}95 \% \text { Confidence Interval of the } \\
\text { Difference }\end{array}$} \\
\hline & & & & & Lower & Upper \\
\hline Markowitz & 2.906 & 17 & .010 & .00680000 & .0018636 & .0117364 \\
\hline
\end{tabular}

Source: SPSS 24 output results (2019)

From Table 6 above, the output shows that the $t$ value is $2.906>t$ table 2.110 , this shows that $\mathrm{Ha}$ is accepted, namely the Markowitz method is accurate in determining the Optimal Portfolio on the LQ-45 group shares on the IDX. Also, the output is Sig. (2-tailed) with a value of $0.010<0.05$, then this also shows that $\mathrm{Ha}$ is accepted, namely the Markowitz method is accurate in determining the Optimal Portfolio on LQ-45 group stocks on the IDX.

Based on the results of Table 6, it is known that the $t_{\text {count }}$ value is $2.906>$ the $t_{\text {table }}$ value is 2.110 with $\alpha=5 \%$ and $d f=17$, the sig. (2-tailed) value is $0.010<0.05$ which states that the Markowitz method is accurate in determining the optimal portfolio of group stocks. LQ-45 on the IDX, so hypothesis 1 is accepted. The Markowitz method calculation model is said to be optimal because it produces the closest expected return 
to market return. Because this method assumes that investor preferences are based solely on the expected return and portfolio risk. Investor preferences have 3 types, namely: investors who are looking for risk (risk seeker), investors who are neutral to risk (risk-neutral), investors who avoid risk (risk aversion). This Markowitz method provides the portfolio value with the smallest risk for a certain expected return, which can be determined by the investor himself.

Following the theory expressed by Markowitz (1952), that is, don't put eggs in one basket, but put them in more than one basket. This theoretical concept is known as diversification or investing that is not centered on just one area but more than one area. The Markowitz model is the first formal model to diversify portfolios with quantitative calculations. Portfolio risk is not only a weighted average, maximizing the return on each asset in the portfolio but also showing the relationship between assets.

Single index method hypothesis testing, namely:

$\mathrm{HO}$ : The Single Index method is not accurate in determining the Optimal Portfolio on LQ-45 Index group stocks on the IDX.

Ha: The Single Index method is accurate in determining the Optimal Portfolio on LQ45 Index group stocks on the IDX.

Table 7. One Sample T-Test with a Single Index Method

One-Sample Test

\begin{tabular}{|c|c|c|c|c|c|c|}
\hline & \multicolumn{6}{|c|}{ Test Value $=0$} \\
\hline & \multirow[b]{2}{*}{$t$} & \multirow[b]{2}{*}{ df } & \multirow[b]{2}{*}{ Sig. (2-tailed) } & \multirow{2}{*}{$\begin{array}{l}\text { Mean } \\
\text { Difference }\end{array}$} & \multicolumn{2}{|c|}{$\begin{array}{c}95 \% \text { Confidence Interval of the } \\
\text { Difference }\end{array}$} \\
\hline & & & & & Lower & Upper \\
\hline Singlelndex & .699 & 17 & .494 & .00131389 & -.0026544 & .0052821 \\
\hline
\end{tabular}

Source: SPSS 24 output results (2019)

From the table above is the output result which shows that the value of Sig. of $0.494>0.05$, this indicates that $\mathrm{HO}$ is accepted, namely the Single Index Method is not accurate in determining the Optimal Portfolio on LQ-45 group stocks on the IDX. Also, the results of the output $t_{\text {count }}$ with a value of $0.699<t$ table, namely 2.110 , so also show that $\mathrm{HO}$ is accepted, namely the Single Index Method is not accurate in determining the Optimal Portfolio on the LQ-45 group shares on the IDX.

The results from Table 7 with the results of $t_{\text {count }} 0.699<t_{\text {table }} 2.110$ and sig. (2tailed) $0.494>0.05$ with $\alpha=5 \%$ and $d f=17$ states that the Single Index Method is not accurate in determining the optimal portfolio in the LQ-45 group stocks. on the IDX, then hypothesis 2 is rejected. Because in this study $\alpha$ and $\beta$ are not constant over time, constructively the expected value of the residual error is not equal to zero.

The Single Index method uses assumptions that are characteristic of this model so that it is different from other models. The main assumption of this Single Index Model is that the residual error of a security is not correlated with the residual error of other securities. The second assumption is the return on the market index $(\mathrm{Rm})$ and the risk error of each security is not covariate (correlated).

The assumptions of the Single Index Model imply that securities move together not because of outside-market effects, but because they have a general relationship to the market index. Thus, how much this model can be accepted and represents the real reality depends on how much realistic these assumptions are. If these assumptions are less realistic, it means that this model will be inaccurate. 
Furthermore, the hypothesis test used in this study is the independent sample ttest. Independent sample t-test is a type of statistical test that aims to compare the means of two groups that do not fit together or are not related to each other. Here's the hypothesis:

H0: There is no difference between the Markowitz Method and the Single Index Method in determining the Optimal Portfolio.

$\mathrm{Ha}$ : There is a difference between the Markowitz Method and the Single Index Method in determining the Optimal Portfolio.

Table 8. Independent Sample T-Test with Markowitz Method and Single Index Method

\begin{tabular}{|c|c|c|c|c|}
\hline \multicolumn{5}{|c|}{ Independent Samples Test } \\
\hline & & & $\begin{array}{l}\text { variances } \\
\text { assumed }\end{array}$ & $\begin{array}{l}\text { Equal } \\
\text { variances not } \\
\text { assumed }\end{array}$ \\
\hline \multirow{2}{*}{$\begin{array}{l}\text { Levene's Test for Equality } \\
\text { of Variances }\end{array}$} & $\mathrm{F}$ & & .295 & \\
\hline & Sig. & & .590 & \\
\hline \multirow{7}{*}{$\begin{array}{l}\text { t-test for Equality of } \\
\text { Means }\end{array}$} & $t$ & & 1.827 & 1.827 \\
\hline & df & & 34 & 32.499 \\
\hline & Sig. (2-tailed) & & .076 & .077 \\
\hline & Mean Difference & & .00548611 & .00548611 \\
\hline & Std. Error Difference & & .00300201 & .00300201 \\
\hline & \multirow{2}{*}{$\begin{array}{l}95 \% \text { Confidence Interval } \\
\text { of the Difference }\end{array}$} & Lower & -.00061470 & -.00062509 \\
\hline & & Upper & .01158692 & .01159732 \\
\hline
\end{tabular}

Source: SPSS 24 output results (2019)

From the table above is the output result which shows that the $t$ value is $1.827<t$ table 2.032, this indicates that $\mathrm{HO}$ is accepted, that is, there is no difference between the Markowitz Method and the Single Index Method in determining the Optimal Portfolio. Also, the output produces sig. (2-tailed), namely 0.076 and $0.077>0.05$, it shows that $\mathrm{HO}$ is accepted, that is, there is no difference between the Markowitz Method and the Single Index Method in determining the Optimal Portfolio. As can be seen from the results of the calculation of Table 8, it is known that $t_{\text {count }} 1.827<t_{\text {table }} 2.032$ and Sig. (2-tailed) 0.076 and $0.077>0.05$ with $\alpha=5 \%$ which states that there is no difference between the Markowitz Method and the Single Index Method in determining the portfolio. optimal.

In the statistical results of the calculation of the two methods, there is no similarity. This situation is due to the data used in this study both using data on closing prices from 2014-2018. Produces the same rate of return and produces the same variance. And each method in this study uses a sample of 18 companies.

\section{CONCLUSION}

The Markowitz method is accurate in determining the Optimal Portfolio. This is due to the calculation of the Markowitz Method which produces the expected return closest to the market return. Because this method assumes that investor preferences are only based on expected return and portfolio risk. The Single Index method is not accurate in determining the Optimal Portfolio. This is because the resulting $\alpha$ and $\beta$ calculations are not constant over time, so constructively the expected value of the residual error is not equal to zero. Because according to this Single Index Method assumption, the residual 
error of a security is not correlated with the residual error of other securities, and it also assumes that the residual error of each security is not covariant (correlated) with the market index return $(\mathrm{Rm})$.

There can be no difference between the Markowitz Method and the Single Index Method in determining the optimal portfolio. This is because the calculations of the two methods both use closing price data from 2014-2018. Produces the same rate of return and variance. And each method uses a sample of 18 companies.

\section{REFERENCES}

Bodie, Z., A. Kane and A.j. Marcus. 2011. Investment, $9^{\text {th }}$ ed., McGraw-Hill/Irwin, New York, N.Y.

Bursa Efek Indonesia. http://www.idx.co.id

Hartono, Jogiyanto. 2013. Teori Portofolio dan Analisis Investasi. Edisi Kesembilan. Yogyakarta. BPFE. Yogyakarta.

Markowitz, H. 1952. "The Journal of Finance" Portofolio Selection. 7(1), 77-91.

Rahmadin (2014) Pembentukan Portofolio Optimal Saham Berdasarkan Model Indeks Tunggal (Studi Pada Saham Indeks Lq-45 Di Bei Tahun 2011-2013) Jurnal Administrasi Bisnis, Vol. 9 No. 2A

Rodoni, Ahmad dan Herni Ali. "Manajemen Keuangan Modern". Jakarta: Mitra Wacana Media, 2014.

SahamOK - Belajar Investasi untuk Pemula, https://www.sahamok.net

Yahoo! Finance/ http://finance.yahoo.com

Zubir, Z. 2011. Manajemen Portofolio (Penerapannya Dalam Investasi Saham). Jakarta: Salemba Empat. 